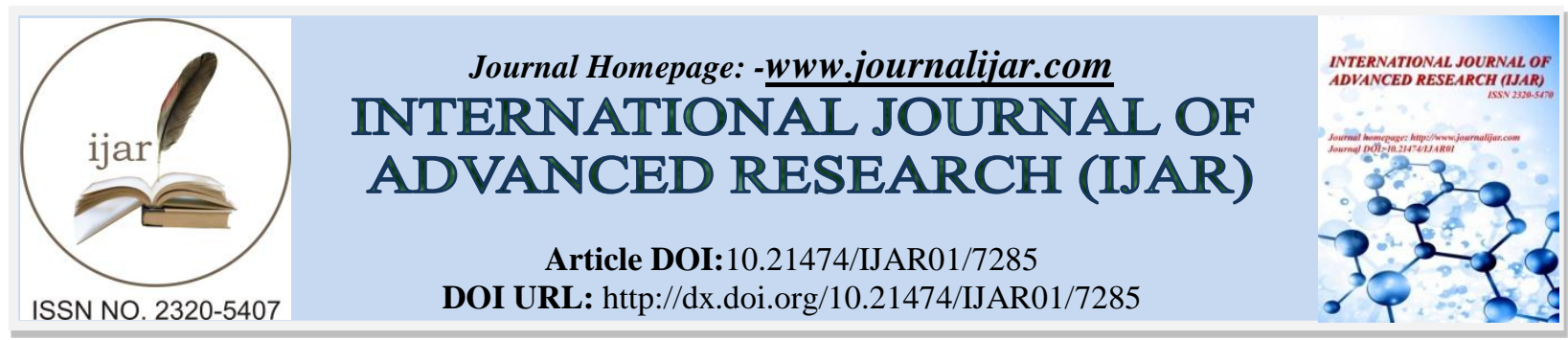

RESEARCH ARTICLE

\title{
THE EFFECTS OF LIVESTOCK GRAZING ON THE SOCIO-ECONOMIC LIVELIHOODS OF THE COMMUNITIES ALONG THE RIPARIAN OF RIVER BENUE, ADAMAWA STATE NIGERIA.
}

\author{
Madube Tumba Kwabe ${ }^{1,2}$, Nuwe John Bosco ${ }^{2}$, Opara A. Jacinta ${ }^{2}$ and Anne Tumushabe ${ }^{2}$. \\ 1. Federal College of Education Yola Adamawa State, Nigeria. \\ 2. Department of Biological and Environmental Sciences, Kampala International University, Kampala, Uganda.
}

\section{Manuscript Info}

Manuscript History

Received: 14 April 2018

Final Accepted: 16 May 2018

Published: June 2018

Keywords:-

Grazing, Socio-economy, Riparian,

Livelihood, Communities.

\begin{abstract}
The study analyses the socioeconomic consequences of grazing in the riparian of River Benue in Adamawa State of Nigeria on the livelihood of its communities. It utilizes survey involving 232 respondents selected randomly from the communities along the riparian area. Data was collected by administering questionnaires to the respondents, while descriptive statistics and Pearson's correlation were used in analyzing the data.

The findings revealed a strong negative relationship at $(\mathrm{r}=0.852, \mathrm{p}<$ 0.05 ), which indicates a negative implication on the sustainability of socio-economic activities among communities situated along River Benue. The study reveals that grazing along the banks of River Benue has affected the socio-economy of the riparian communities which include decrease in habitat for fish production, decrease in wild foods and medicinal plants, decrease in cultural and recreational potentials etc. The study further reveals disparity in the socio-economic effects of grazing on the livelihoods of the riparian in the upper and lower section of the river.
\end{abstract}

Copy Right, IJAR, 2018,. All rights reserved.

\section{Introduction:-}

Grazing abounds across the world with differences in effects due to variation in climate and culturally conceptualization of grazing management strategies by communities. Regardless of the conceptualization of grazing management strategies, grazing still seems to be the most disastrous action in few countries where uncontrolled or unregulated practices exist. Upland vegetation grazing is as old as crop cultivation among most of the communities in Nigeria, especially among communities in the savanna region of North Eastern Nigeria, where an unguided open cattle grazing has caused a serious problem of overgrazing (Adefioye, 2013). However, prior the post-independent era, grazing activities were not common along the riparian due to limited economic, technological adaptation and prevalence of tsetse fly (Adefioye, 2013). Although riparian grazing seems to be a recent development, it seems to be more devastating across Africa countries, especially in Nigeria along the riparian of river Benue.

The effects of livestock grazing on the environment has been identified to include defoliation, trampling and browsing on plants (Zoheir, 2011). This has led to a redistribution of nutrients, redistribution of plant seeds by passive transportation and by other propagules. Livestock management has been and still is a huge source of livelihood for a large percentage of both rural and urban dwellers in Nigeria (Oyinloye, 2011). Like in the pre- 
settlement time, grazing is mostly traditionally managed in Nigeria with variation in the practices limited to communities or regions.

For a long time, there has been conflict between livestock grazing and sustainability of the riparian vegetation. There is need for sustainability of the riparian environment because of its critical support to the biodiversity and the society. Thus, this calls for sustainable and proper management of livestock grazing in every society. Despite improvements in economic and technology in Nigeria the traditional methods of grazing are still in use in the north east of Nigeria among communities and the nomadic pastoralists. This has become a serious concern to the communities of the Savanna region of Nigeria, where livestock grazing has become a challenge (Adefioye, 2013; Blench, 2010).

The riparian vegetation in Nigeria was well developed with stable vegetation heterogeneity before the improvement in Nigeria economy coupled with population growth (Blench, 1999; Onoaha, 2008). Also, prior to postindependence, the profound influence of grazing was associated with terrestrial vegetation (Aremu \& Onadeko, 2010) with the communities having their own traditional ways of managing resources (Meagher and Yunusa, 2012). Consequently, every community in Nigeria has its own customary policies used in safe guarding land and other natural resources (Meagher \& Yunusa, 2012). Thus, the riparian vegetation conditions were then in good conditions and stable with efficient ecological services, which were relatively free from human activities. Also, the vegetation community was wide matured with standard succession level which provided to the community's efficient ranges of non-farming social and economic opportunities (Olaotswe, et al., 2013).

At the post-independent Nigeria, grazing drifted into the riparian areas due to the exhausted conditions of the terrestrial vegetation, and the demands for animal protein (Adefioye, 2013). Subsequently, uncontrolled grazing became a serious problem in the riparian thereby affecting the farming and non-farming opportunities along the riparian on which most of the community's livelihood depends (Meagher and Yunusa, 2012). Thereby, studies carried out on livestock grazing (Capper, 2013, Scholtz.et al., 2013, IFAD, 2013.) showed that there has been a major environmental impact of livestock on plant community, land, water and biodiversity.

According to Seré (2012), livestock systems occupy 45 percent of the earth's surface. In South Africa 70 percent of the agricultural is utilized by livestock (Meissner. et al., 2013) while 75 percent of land in Namibia is used for extensive livestock ranching (Lange. et al., 2011) and cattle production alone occupies 75 million hectares in Northern Australia (Macleod. et al., 2014). However, livestock production is generally assumed to be adversely affected by land degradation, which eventually reflects on the economic performance (Macleod. et al., 2014).

Poor management of livestock grazing is evident of overgrazing resulting from overstocking beyond the lands' carrying capacities, which exposes pastureland and riparian loss of vegetation. Macleod et al., (2014) examined the productivity of livestock under different grazing regimes; and they found that changes in plants and land conditions had both positive and negative effects on livestock production. The link between vegetation condition, livestock grazing, and economic outcomes was determined using a combination of experimental data and simulating models. It was established that as plants and land conditions deteriorate, reduction in livestock numbers was warranted (Meissner. et al., 2014). Extreme cases of poor floristic and land conditions with high livestock numbers resulted in poor livestock performance, with poor market value and hence low profitability.

However, economic activities such as fishing, farming, weaving, hunting, transportation (navigation), among others are the common effects of overgrazing along the riparian (Adefioye, 2013). The communities living along river Benue are mixed-up with a reasonable number of Nomadic and Agro-pastoralists who keep large herds of cattle and some few goats and sheep, which has serious negative implications on the non-farm activities' (Meagher and Yunusa, 2012).

Grazing as one of the most dominant economic activities has resulted in degradation of vegetation, land, and water over the years, which impacted negatively, the non-farming and farming economic and social opportunities along the riparian (Adefioye, 2013 and Blench, 2010).

Furthermore, due to the nomadic lifestyle and struggle for control of riparian resources in Nigeria, there have been incessant conflicts around the riparian area that is already becoming a norm due to limited grazing areas. Lives, property, and animals have been lost in these conflicts over the years, and little has been done by the local, State and 
Federal authorities (Linus. et al., 2014). This study assesses the effects of unregulated grazing activities on the socio-economic livelihoods of people living along the riparian of River Benue in Adamawa state, Nigeria.

\section{Materials and Methods:-}

The study was conducted in the riparian area along the River Benue from Lamurde and the areas to the River Gongola tributaries, extending up to Fufore in the upstream in Adamawa State that lies on latitudes $7^{0} .28^{\prime}-10^{0}-56^{\prime}$ north and Longitude $11^{0} .30^{\prime}-13^{0}, 75^{\prime}$ east. A cross-sectional descriptive survey was used and it adopted quantitative and qualitative approaches. Simple Random sampling and stratified samplings were used in identifying the categories of sample population along the riparian. Study sample size was derived from five selected categories based on the nature and structure of the communities. It comprised of (1), River basin development authority (65), (2), Adamawa state environmental management agency (55), (3) Community based organizations (36), (4), Nongovernmental Organisations (12), and (5) Local community members (382). Thus; a representative sample of 232 respondents from the target population of 550 was attained. The study administered questionnaires to the respondents to achieve the objectives of the research which is to determine the social-economic effects of grazing along the riparian of River Benue in Adamawa state of Nigeria on its communities. To validate the effect of grazing on some of the plants of economic importance, two transects of $1000 \mathrm{~m}$ with alternate plots of $50 \mathrm{~m} * 50 \mathrm{~m}$ in the grazed and ungrazed land were made. Plants were identified, counted in each plot and a total number were recorded.

\section{Data Analysis:-}

Responses were presented using descriptive statistics such as frequencies, percentages, tables, and charts. A Pearson's correlation was used to determine the relationship between the unregulated grazing activities and the socio-economic livelihoods of people living along riparian of River Benue in Adamawa State of Nigeria. To assess the distribution of the plants in grazed and ungrazed land, total means of the particular plants of economic importance along the transects were determined (Table 1) to show the distribution along the riparian.

\section{Results:-}

The figure 1 below expresses the effects of grazing on the social functions of the communities along the riparian of the River Benue..

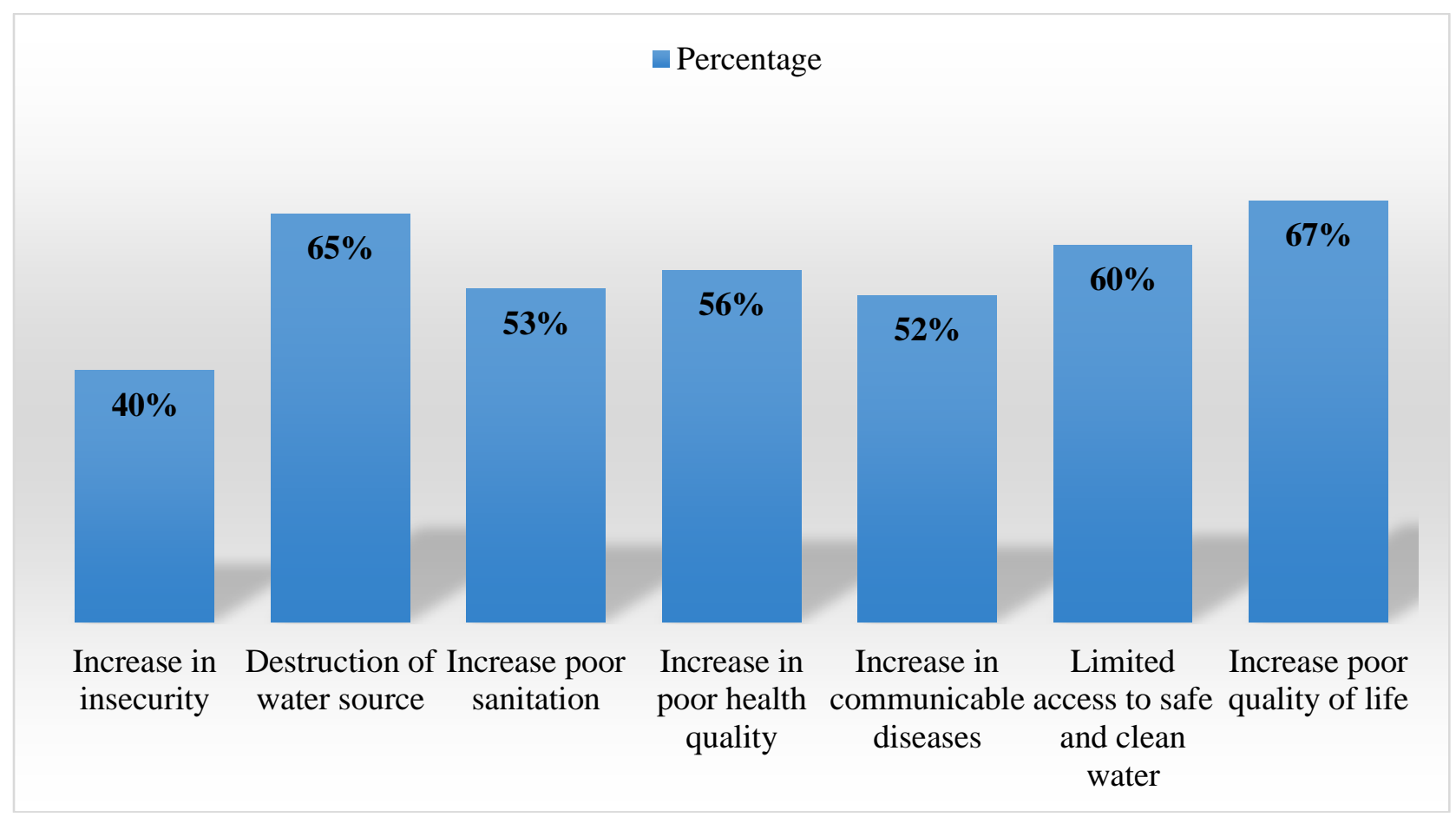

Figure 1:-The Social effects of grazing on the community along the riparian 
A line graph was used to demonstrate the variation in the social consequences of grazing amidst the communities (Figure 2), and it showed the lower section of the riparian having the more severe weight of the effects compared to the upper section. Demsa is mostly affected with 17.8 percent of asperity of all the challenges, followed by Lamurde area at 15.8 percent crabbiness and Numan areas with 15 percent tartness to the prevalence respectively. In the upper section, Yola South is most affected by 15 percent sourness of the challenges, Fufore 13.4 percent astringency of the effect on community and Girei with 12.7 percent experiences of challenges bitterness to the actuality of effects and Yola North with 9.9 percent less experiences of challenges severity.

Social effects of grazing amidst the communities

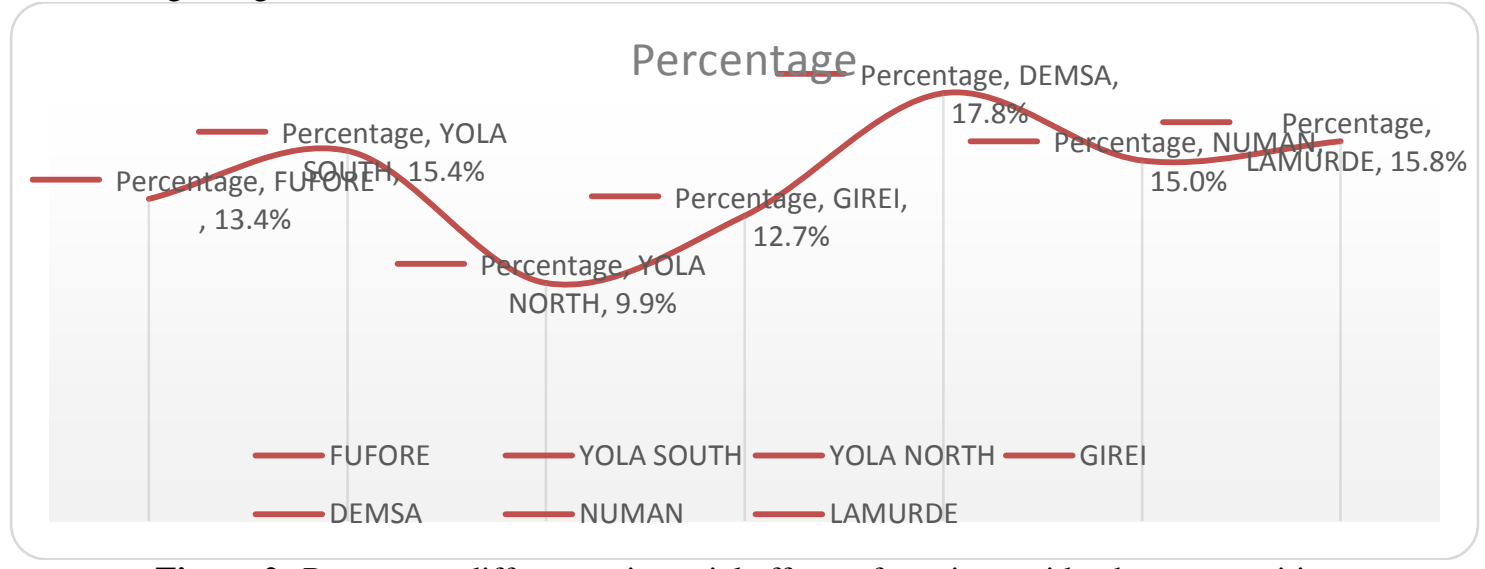

Figure 2:-Percentage differences in social effects of grazing amidst the communities

The economic effects of grazing on community livelihood along the riparian of River Benue

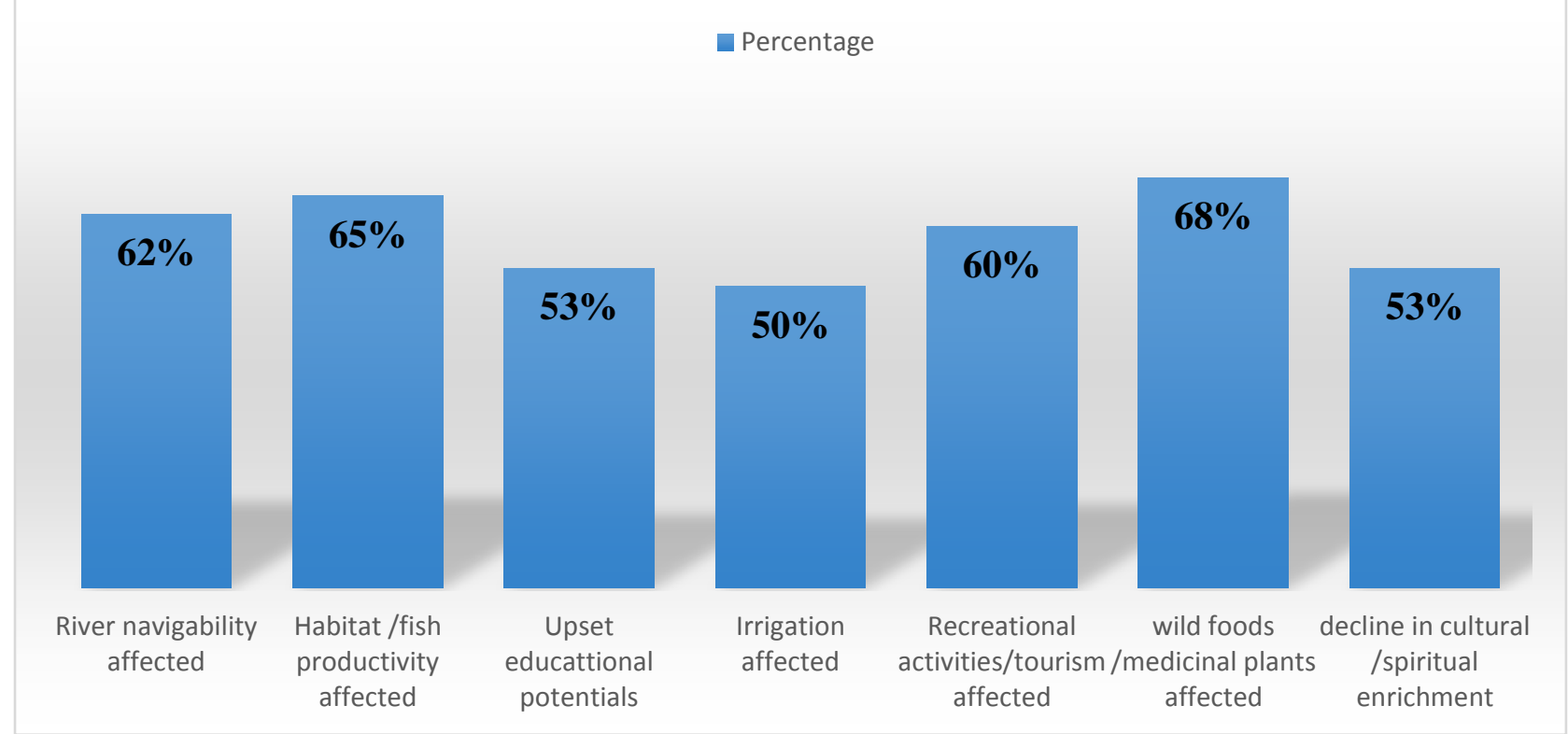

Figure 3:-Economic effects of grazing on communities along the riparian area

Figure 3 above indicates that grazing has an economic backlash on the communities along the riparian area. Most common and severe of the effects include; decrease in wild foods (e.g., Hack berry, Anacardium occidentale) and medicinal plants (68\%), destruction of habitat and Fishery productivity $(65 \%)$ and decrease in the navigability of riparian water for transportation and other functions (62\%). Other effects such as disruption of recreational activities, the decline in irrigation destruction of spiritual and cultural enrichment of the riparian vegetation were also mentioned. 
Differences in the economic effects of grazing amidst the communities along the riparian

\section{Percentage}

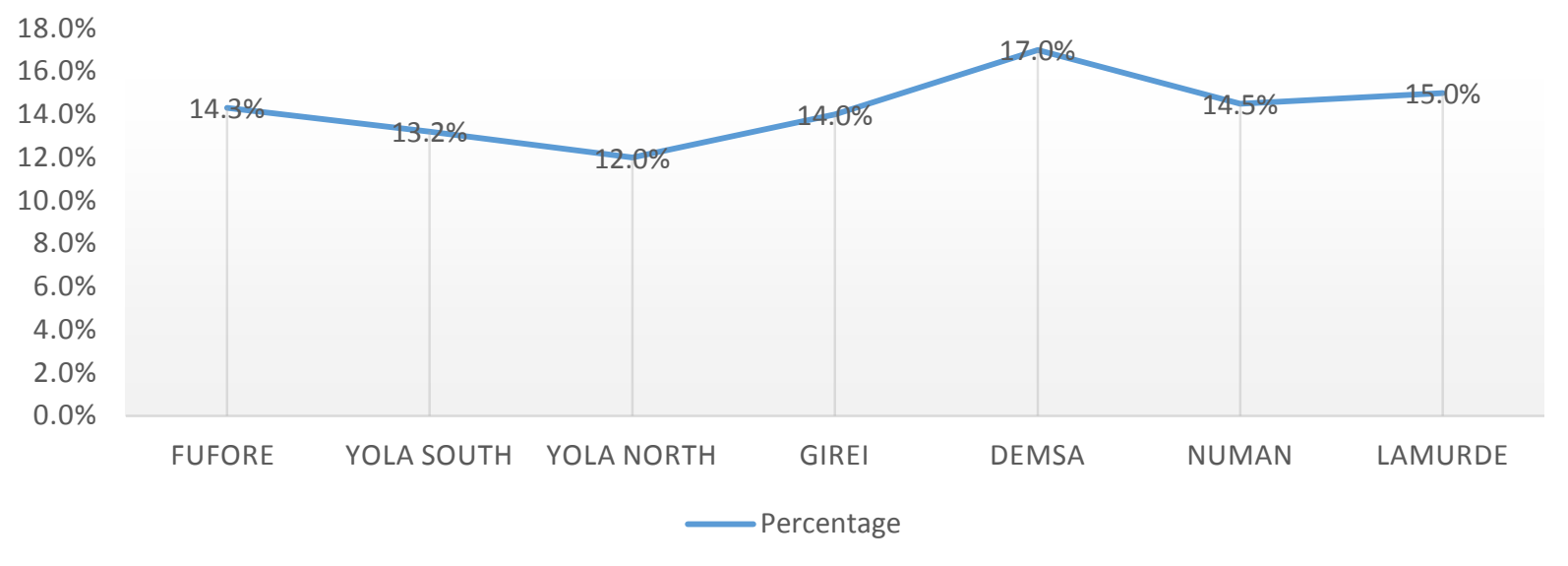

Figure 4:-Percentage differences in the economic effects of grazing amidst the communities

Figure 4 findings indicate that there is a great difference in the economic consequences of grazing in the communities along river Benue. Communities in the lower section of the riparian are more affected than those in the upper section. Demsa is most affected with 17 percent astringency; followed by Lamurde 15 percent asperity and Numan 14.5 percent bitter experience. In the upper section of the riparian, Girei is most affected with 14 percent severity, while Yola North 12 percent sourness, Yola South 13.2 percent asperity and Fufore within the range of 14.3 percent of the challenges astringency respectively.

A relationship between grazing and socio-economic livelihoods of the communities was determined using Pearson Correlation $\left(\mathrm{r}=0.852^{*}, \mathrm{p}<0.05\right)$ (Table 2$)$ and it showed that grazing has a negative implication on the sustainability of socio-economic activities among the communities along riparian of river Benue. This indicates that, as grazing increases in the riparian, there is more deterioration of the socio-economic activities and livelihoods of the communities along the riparian area.

Table 2:-Pearson correlation analysis of socio-economic effects of grazing on the communities' livelihoods

\begin{tabular}{|l|l|l|l|}
\hline \multicolumn{2}{|c|}{} & $\begin{array}{l}\text { Social economic effects } \\
\text { of grazing }\end{array}$ & $\begin{array}{l}\text { People's } \\
\text { livelihood }\end{array}$ \\
\hline \multirow{3}{*}{ Social economic effects of grazing } & Pearson Correlation & 1 & $.852^{*}$ \\
\cline { 2 - 4 } & Sig. (2-tailed) & & .000 \\
\cline { 2 - 4 } & $\mathrm{N}$ & 230 & 230 \\
\hline \multirow{3}{*}{ Deterioration in People's livelihood } & Pearson Correlation & $.852^{*}$ & 1 \\
\cline { 2 - 4 } & Sig. (2-tailed) & .000 & 230 \\
\cline { 2 - 4 } & $\mathrm{N}$ & 230 & \\
\hline
\end{tabular}

\section{Discussion:-}

The study found that the social effects commonly experienced by the respondents included; the prevalence of insecurity increased risks of contracting communicable diseases and destruction of water source for drinking. Others effects such as the reduced potential for recreational, fishing, swimming and boating in the area as found in Linus, et al., 2014 were also mentioned. This has contributed to declining in eco-tourism activities, destruction of medicinal plants and the decline in navigability of the river which has affected transport business and practices of herbal medicine.

Intensive grazing in riparian is not only on the plant community resources, but it creates conflicts between the communities and herdsmen which generate huge social implications (Meagher and Yunusa, 2012; Linus. et al., 2014). The effect is more disastrous in Demsa which has the highest percentage, followed by Numan and Lamurde 
respectively. Categorically, settlements are rural in these communities with most of their social livelihood activities relying heavily on the riparian resources along the river.

The most common economic effects on the livelihood of the communities included among others; destruction of fish habitat and a decrease in fish productivity and wild life which is another source of income and protein for the community. Using Pearson correlation, the results indicated a high effect on the livelihoods $(r=0.852)$ at $(\alpha=0.05)$ hence need to check the situation if poverty levels are to reduce.

In addition, livestock grazing affects the riparian environment by changing and reducing vegetation or by the actual elimination of riparian areas by channel aggradation or lowering of the water table through plant degradation (Macleod. et al., 2014). This is experienced in Benue as vegetation degradation has occurred immensely and contributed to declining in fish catch and reduced food supply. Resultant increases in stream temperature; decline in wild fruits along the stream, a decrease of debris cover through plants degradation has also been experienced. This is in agreement with McIntosh. et al., (2013) and Armour. et al., (2011), that found out that stream vegetation degradation has long been recognized as a major watershed-fisheries problem and general ecological services. The elimination of stream bank vegetation due to acute livestock grazing is a serious negative development to all vegetative dependent riparian components. In the grazed site of the riparian, stream vegetation was degraded because livestock congregates along streams for shade, succulent riparian vegetation, and drinking water.

Some economic plant species that have been affected along the riparian include; hackberry and cashew apple, produced naturally by cashew tree (Anacardium occidentale), Nigerian leafy vegetables such as Wild Lettuce locally known as (Efo Yarin -Yoruba) and Crassocephalum rubens locally known as the (Yoruban bologi Ebolo), Crassocephalum rubens (the Yoruban bologi Ebolo), Crassocephalum crepidiodes, Vernonia amygdalina, . These have reduced both in diversity and distribution in the grazed land as shown in table 1 below. This has economically affected the livelihood of the communities as they were harvested and sold for food, medicine, ornamental purpose and therefore income, medicinal and the nutritional value has been compromised.

Table 1:-Plants distribution of the most dominant species in the study sites

\begin{tabular}{|l|l|l|l|}
\hline Species Name & Life form & $\begin{array}{l}\text { Frequency in } \\
\text { Grazed Riparian }\end{array}$ & Frequencies in ungrazed \\
\hline Virtex Doliana & Tree & 10 & 40 \\
\hline Bataytics sperman & Tree & 11 & 35 \\
\hline Eucalyptus spp & Tree & 20 & 46 \\
\hline Ziziplus spinadinsti & Tree & 9 & 45 \\
\hline Balanites aegyptiaca & Tree & 10 & 30 \\
\hline Acacia ivarensis & Tree & 10 & 26 \\
\hline Acacia senegalensis & Tree & 16 & 35 \\
\hline Termarindus indica & Tree & 13 & 27 \\
\hline Tricalysia negerica & Shrub & 10 & 30 \\
\hline Tarupin & Shrub & 16 & 42 \\
\hline Tricalysia wrahaniana & Shrub & 12 & 40 \\
\hline Tricalysia abanensus & Shrub & 10 & 26 \\
\hline Sabicea langinosa & Shrub & 16 & 35 \\
\hline Rytizynia aryantea & Shrub & 21 & 48 \\
\hline Allophysus nigericus & Shrub & 30 & 56 \\
\hline Prunus Africana & Shrub & 31 & 50 \\
\hline Sansevera liberica & Shrub & 14 & 28 \\
\hline Acacia nilotica & Shrub & 10 & 35 \\
\hline Mimosa pudica & Shrub & 10 & 29 \\
\hline Carculinta moschola & Shrub & 7 & 28 \\
\hline Solanum nigeum & Shrub & 9 & 30 \\
\hline Lecnurus sibiri & Shrub & 11 & 52 \\
\hline Annoria spp & Shrub & 9 & 26 \\
\hline Grater sahel & Shrub & 25 & 54 \\
\hline Asptenium comutumaistan & Shrub & 21 & 32 \\
\hline & & & \\
\hline
\end{tabular}




\begin{tabular}{|c|c|c|c|}
\hline Indegofera lotisepola & Shrub & 23 & 49 \\
\hline Alectra virgata herns & Shrub & 19 & 28 \\
\hline Chlorphytum dalzieri & Grass & 11 & 30 \\
\hline Aeschynarnene neglecta & Grass & 13 & 33 \\
\hline Hepper & Grass & 12 & 34 \\
\hline Labiates spp & Grass & 20 & 44 \\
\hline Tridx combretum & Grass & 37 & 60 \\
\hline Pacunium spp & Grass & 27 & 62 \\
\hline SorghumVulgare & Grass & 30 & 66 \\
\hline Panicum maximum & Grass & 9 & 28 \\
\hline Floating grass & Grass & 11 & 40 \\
\hline Tuft Damaliligel & Grass & 17 & 29 \\
\hline Strychirus nuxvorica & Grass & 20 & 46 \\
\hline Gynandopsis synandra & Grass & 24 & 54 \\
\hline Nymphoea lotus & Grass & 30 & 56 \\
\hline Pristia stratiotes & Grass & 9 & 27 \\
\hline Commelina Beughalensis & Grass & 40 & 64 \\
\hline Ipomoea spp & Grass & 15 & 37 \\
\hline Hyparrhenia spp & Grass & 30 & 54 \\
\hline Anogneissus spp & Grass & 31 & 50 \\
\hline Ipomea acquatic & Grass & 13 & 46 \\
\hline Maginfera indica & Grass & 20 & 57 \\
\hline Walitenbergiara mosissima & Grass & 18 & 37 \\
\hline Thulin sibsppra mosissima & Grass & 13 & 54 \\
\hline Batulia termulcaulis & Grass & 31 & 50 \\
\hline Helich Comer canines & Grass & 25 & 46 \\
\hline Stiches pseudohamritusa & Grass & 16 & 45 \\
\hline Nymphaelotus haolatus & Grass & 14 & 40 \\
\hline Satribia molesta & Grass & 16 & 28 \\
\hline Hibiscus sineoculeotus & Grass & 10 & 24 \\
\hline Indigefera hutchinsoniana & Herb & 13 & 26 \\
\hline Raphia mambillenisis & Shrub & 25 & 46 \\
\hline Azolia African & Grass & 27 & 46 \\
\hline Commelina benghal ensis & Forbs & 16 & 38 \\
\hline Cypenus spp & Forbs & 14 & 42 \\
\hline Leersia hexandra & Grass & 13 & 38 \\
\hline Water hyacinuth & Grass & 10 & 33 \\
\hline Raphia sudanica & Tree & 23 & 56 \\
\hline Phonixdactylifera & Tree & 11 & 33 \\
\hline Xeromphis nilotica & Shrub & 22 & 46 \\
\hline Khaya senegalensis & Tree & 9 & 41 \\
\hline Adansonia digitata & Tree & 11 & 32 \\
\hline Azadiracta indica & Tree & 20 & 46 \\
\hline Asperula canferta & Forbs & 16 & 35 \\
\hline Boerhavia dominii & Forbs & 15 & 36 \\
\hline Salsola tragus & Shrub & 13 & 3 \\
\hline HackBarry & Shrub & 13 & 38 \\
\hline Anacardium occidentale & Tree & 9 & 30 \\
\hline Leonurus sibiricus & Shrub & 11 & 27 \\
\hline Lactuca salinga & Shrub & 12 & 32 \\
\hline Parkia spp & Tree & 7 & 40 \\
\hline Hevea biasilliensis & Tree & 9 & 41 \\
\hline Crassocephalum rubens & Shrub & 12 & 28 \\
\hline
\end{tabular}




\begin{tabular}{|l|l|l|l|}
\hline Vernonia amygdaline & Tree & 14 & 38 \\
\hline Moringa oleifera & Tree & 20 & 45 \\
\hline Celtis Africana & Grass & 15 & 46 \\
\hline Themeda triandra & Grass & 10 & 43 \\
\hline Cynodon dactylon & Grass & 9 & 50 \\
\hline Prunus Africa & Grass & 9 & 50 \\
\hline Larissa spinarum & Shrub & 8 & 32 \\
\hline Angylocorlyx oligophyllus & Grass & 20 & 47 \\
\hline Aristida mutabilis & Grass & 16 & 49 \\
\hline Chlorophytum dalziere & Grass & 20 & 30 \\
\hline Rucinus cominunis & Grass & 15 & 31 \\
\hline Imperata cylinderic & Grass & 24 & 32 \\
\hline Chytrantasusmacrobotrys & Grass & 15 & 29 \\
\hline Denhous cilliaris & Grass & 16 & 3 \\
\hline Euphorbiaceae & Tree & 18 & 5 \\
\hline Mumosaceae & Tree & 20 & 10 \\
\hline Sterculiaceae & Tree & 03 & 54 \\
\hline Carissa spinarum & Grass & 01 & 50 \\
\hline 1. Celtis Africana & Grass & 04 & 51 \\
\hline Senecio abyssinia & Grass & 06 & 52 \\
\hline & & 1534 & 3763 \\
\hline
\end{tabular}

\section{Conclusion:-}

Livestock grazing has affected the riparian environment immensely in different ways and this has been attributed to lack of adoptability and utilization of modern grazing management strategies in Adamawa State. The sustainability of the riparian areas is a serious environmental concern due to the presence of the local open and unregulated traditional grazing method. Improper grazing along the riparian has damaged the riparian vegetation which inversely has damaged other vital components of the system. The degraded plant community has reduced the potential for recreational, fishing, business and nutritional values in the area and also created conflicts among herdsmen and the communities. Therefore, there is need to empower public in understanding that, having a healthy riparian ecology is a strong mitigation measure against climate change impingement. Government at Federal, State, Community leaders and Community Base Organisations should revegetate the riparian with reasonable plant species of riparian character to help prevent or minimize the negative effects of livestock grazing in riparian as well as provide reasonable land for the establishment of ranches to control unregulated open grazing.

\section{References:-}

1. Adefioye S.A. (2013).Analysis of land Use/Land cover pattern along the River Benue channelinAdamawaState,Nigeria:AcademicJournalofinterdisciplinarystudies, 2(5)MSCER-CEMAS.

2. Armour,C.L.,Duff,D.A.,\&Elmore,W.(2011).TheEffectsofLivestockGrazingon RiparianandStreamEcosystems.Journaloffisheries, 16(1);7-11.

3. Aremu,O.T.,Onadeko,S.A.,\&Inah,E.I.(2010).ImpactofGrazingonForageQuantityand Quality for Ungulates of Kainji Lake National Park Nigeria,Journalof Applied Sciences,(1)-1800-1804. Blench, R. (2010), The transformation of conflicts between the Pastoralists and cultivators in Nigeria DFID.

4. Blench, R. (2010), The transformation of conflicts between the Pastoralists and cultivators in Nigeria DFID.

5. Bradford, M. \& Ernest, S.(2013).Current usage of symbiosis and associated terminology. International JournalofBiology,5(1):1-32.doi:10.5539/ijb.v5n1p32.

6. Capper, J.L. (2013). Should we reject animal source foods to save the planet? A review of the sustainability of global livestock production. South African Journal of Animal Science, 43(3), 233-246.

7. Charles, K.(2010).A Negotiated Frame works for Rehabilitation of Riparian Zones in Nairobi City: Available from http:/isocarpnet/data/case-studies/1780.Pdf.

8. Dossely,M.,Vidon,P.,Garwick,N,P.,Allen, G.J.,Dural.T.P.,\&Lawrence,R.(2010). The role of Riparian Vegetation in protecting and improving chemical water quality instream, Journal of America water Resources Association, 40,260. 
9. FAO(2009). The state of food and Agricultural Livestock in the Balance: Food and Agricultural organization of united Nation, Publication.

10. Gunderson, D.R.(1968).Flood plain use related to stream morphology and fish populations. J.ld.]. Manage.32(2),507-514.

11. Herrero, M., Grace, D., Nsuki, J., Johnson, N., Enahoro, D., Silvestri, S. and Rufino, M.C. (2013). The role of livestock in developing countries. International Journal of Animal Bioscience, 7:3-18.

12. HoganC.(2013BenueRiver,Retrievedon29 ${ }^{\text {th }}$,December,2016;from http://www.eoearth.org/view/article/228342.

13. International Fund for Agricultural Development (IFAD) (2013). Smallholders, food security, and the environment, IFAD publishers, Rome.

14. Jansen,A.,\&Robertson,A.I.(2012).Grazing, ecological condition and biodiversity in riparian river redgum forests in south-eastern Australia ',Proceedings of the Royal SocietyofVictoria,117(1),85-95.

15. Lange, G., Barnes, J. and Motinga, D. (2011). Cattle numbers, biomass, production and land degradation in the commercial farming sector of Namibia. Development Solutions Africa, 15(4), 555.

16. Linus B. G., Amos, S. O., Michael, E. T., \& Ensenga, G.M. (2014). Fishing Communities and Fishing as livelihoods in Adamawa state. Direct Research. Journal of agriculture and food sciences, 2 (11); 154 -204.

17. Macleod, N.D., Ash, A.J., \& McIvor, J.G. (2014). An economic assessment of the impact of grazing land condition on livestock performance in tropical woodlands. Rangel Journal, 26(1), 49-71.

18. Meagher,F.,\&Yunusa,K.(2012).Ifthe drumming change, the dance also changes deagrarianisaion and rural nonfarm employment in the Nigerian Savanna African studies center, Leiden.

19. Meissner, H., Scholtz, M., \& Palmer, A. (2013). Sustainability of the South African livestock sector towards 2050. Part 1: worth and impact of the sector. South African Journal of Animal Science, 43(3), 282-297.

20. Nyariki, D.M., Mwang'ombe, A.W., \& Thompson, D.M. (2009). Land-use change and livestock production challenges in an integrated system: The Masai-Mara ecosystem, Kenya. Journal of Human Ecology, 26(3), 163173.

21. Olaotswe, E.K., Witness ,M.,\& Barbra A.H.(2013).Grazing management system and their effects on savanna eco system dynamics: A Review journal of ecology and the natural Environmental,5(16);3-64.

22. Onouha F.C.(2008).Saving Africa Shrinking lakes through inter- basin water transfer reflections on the proposal Lake Chad replenishment project. Nigeria journal of international Affairs,34(2);34-45.

23. OyinloyeM.,\&Kufoniyi,A.(2011).Analysisoflanduse,landcoverandUrbanExpansion inAkure,Nigeria.JournalofinnovativeResearchinEngineeringandscience,2(4).

24. Sarr, D., Knapp, R.A., Owens, J., Balser, T., \& Dudley, T. (2009). Ecosystem recovery from livestock grazing in the southern Sierra Nevada. Aldo Leopold Wilderness. Res. Insti., Missoula, MT.

25. Scholtz, M.M., Van Ryssen, J.B.J., Meissner, H.H., \& Laker, M.C. (2013). A South African perspective on livestock production in relation to greenhouse gases and water usage. South African Journal of Animal Science, 43(3), 1-9.

26. Zhou,S.(2012).Effectsofwildernesstraininggiantpandas?Grazingandartificial harvestingonclonepopulationbiomassofumbrellabamboo.ChineseJournalof AppliedandEnvironmentalBiology.18(1):1-18.

27. Zoheir,A.(2011).Livestockgrazingandriparianareas:ALiteratureReview.Grazingand PastureTechnologyProgram. 